\title{
Identification of Perceived Self-Efficacy to Predict Student's Awareness in Career Readiness
}

\author{
Alfaiz Alfaiz ${ }^{1 *}$, Hendra Hidayat ${ }^{2}$, Hengki Yandri ${ }^{3}$, Aprilia Tina Lidya Sari ${ }^{4}$, \\ Fendahapsari Singgih Sendayu ${ }^{5}$, Septya Suarja ${ }^{1}$, Arjoni Arjoni ${ }^{6}$ \\ Sekolah Tinggi Keguruan dan Ilmu Pendidikan PGRI Sumatera Barat, Indonesia ${ }^{1}$ \\ Universitas Negeri Padang, Indonesia ${ }^{2}$ \\ Institut Agama Islam Negeri Kerinci, Indonesia ${ }^{3}$ \\ Universitas Negeri Yogyakarta, Indonesia ${ }^{4}$ \\ Universitas Palangka Raya, Indonesia ${ }^{5}$ \\ Institut Agama Islam Negeri Bukittinggi, Indonesia ${ }^{6}$ \\ @alfaiz.science.icp@gmail.com*
}

Article Information:

Received May 18, 2020

Revised June 1, 2020

Accepted February 15, 2021

Keywords: awareness; career readiness; self-efficacy

\section{Abstract}

Research found that self-efficacy has an important role in the development of students' career cognitive skills. Besides, there still needs further research in self-efficacy, particularly in career readiness. The authors conduct this continuing study is to determine the effect of understanding perceived self-efficacy on student's awareness in career readiness (mastery experience, vicarious experience, social persuasion, and emotional arousal). Data collected using a self-report of the Self-Efficacy Scale in Career Readiness (SESCR), semi-structured interview, and observation of student's behavior between both participants with the high and low level of self-efficacy. In the current study, 100 students involved based on their convenience. Results showed that $66 \%$ of participants have a high mastery experience, $69 \%$ with high vicarious experience, $76 \%$ have a high percentage in social persuasion, and $70 \%$ have a high level of emotional arousal to understanding their career readiness. The results also showed perceived self-efficacy predicts student's awareness of career readiness based on gender.

\section{INTRODUCTION}

In the past eight years, the development of industry and technology has advanced rapidly through computerized systems, online, e-commerce, and robotics. This era is the phase of the industrial revolution 4.0 which is a big challenge in the education system in Indonesia as a developing country. Also the globalization of education in ASEAN (Association of Southeast Asian Nations) countries with the ASEAN Economic Community (AEC) which contains an international education system that can build education and economy in ASEAN countries so it forms competitiveness and collaboration among countries (Kemendikbud, 2010; Wicaksono, 2007; Chongvilaivan, 2016). To answer the questions, the Indonesian government made many changes to the education system, especially at the college level, which is a educational institution that prepares a generation who has skilled, characterized and capable in their fields ready for a career (Kemendikbud, 2010).

The generation who has character that has a distinctive indication and has a tendency that reflects the behavior, attitudes, mindset and response that illustrates a particular form of uniqueness and capabilities of the individual (Boeree, 2004). Individuals who have character

How to cite:

E-ISSN:

Published by:
Alfaiz, A., Hidayat, H., Yandri, H., Sari, A., Sendayu, F., Suarja, S., \& Arjoni, A. (2021). Identification of Perceived Self-Efficacy to Predict Student's Awareness in Career Readiness. Islamic Guidance and Counseling Journal, 4(1). https://doi.org/10.25217/igcj.v4i1.933 2614-1566

Institut Agama Islam Ma'arif NU (IAIMNU) Metro Lampung 
and strength of unique self capabilities are understood to have high self-confidence strength or called high self-efficacy (Bandura, 1986, 1997). Self-efficacy in the context of social cognitive theory sees humans as individuals who learn from modifying their learning experiences (Bandura, 1997, 2000) through four sources of self-efficacy, namely the experience of performance, vicarius experience, social persuasion and emotional states (Bandura, 1986, 2009; Pajares, 2006, 2002).

Abundant research has been conducted about self-efficacy in learning. That because self-efficacy has an important aspect in the development of students' learning skills, such as self-efficacy being an aspect of mediating student achievement motivation (Bandura, 1978, 1977; Alfaiz \& Yandri, 2015, Alfaiz et al., 2017a) which said that the perception of students' self-efficacy in learning was a factor in learning achievement, a source of performance experience in student's experience (Gao et al., 2011), And self-efficacy also determiners the factor in academic settings, that is students who are low in collaborative learning in class increases with the persuasion cooperation among students in learning (Allred et al., 2013). In academic settings to prepare for career direction is also proven that self-efficacy has a deciding factor in expertise and capabilities for improving career cognitive skills (Krumboltz et al., 2011; Cramer et al., 2004). Even self-efficacy is also a factor forming an individual's agentic power (Alfaiz et al., 2020) in planning, determining, acting up to evaluating learning behavior and even career cognitive behavior (Cauce \& Gordon, 2012; Bandura, 2018; Reeve \& Tseng, 2011; Alfaiz et al., 2019a). Within the found of research above, efficacy can be a psychological aspect that considered as an aspect to improving and understanding student's readiness in their career choose because that linked with their experience and expertise that they have in learning academic (Alfaiz et al., 2019b).

\section{Rationale of the Current Study}

Related to some researches, explaining that self-efficacy has a strong contribution to cognitive activity and individual skills in planning, acting to evaluate the results of behaviors in learning and result in career awareness. However, research is rarely conducted relating to the awareness of students in their career readiness viewed from the aspect of self-efficacy perceptions such cognitive awareness. That aimed at the scientific context of guidance and counseling in higher education, which although previous research that conducted in 2015 provides the potential for this research.

\section{Objectives}

So this study aims to uncover the conditions of self-efficacy perception and the condition of students' awareness of career readiness, and the phenomenon of understanding behavior of students' self-efficacy perceptions in their career readiness from aspects of performance experience, vicarious experience, social persuasion and emotional arousal of students related to their confidence in their career readiness and also prediction of contribution variable self-efficacy to students' awareness in career readiness using regression analysis. Through the instrument of SESCR instrument, that develop by authors from self efficacy aspect (Bandura, 1997) and career awareness (Cramer et al., 2004), interviews and observations will be conducted to answer a third of research purpose above.

\section{METHODS}

\section{Research Design}

The type of this research is a descriptive statistical study with percentage analysis, which aims to describe and identify the condition of the perception of self-efficacy in awareness of career readiness (Umar, 2008). Then, the results confirmed with qualitative 
analysis to uncover the phenomenon of students' self-efficacy in their career readiness and compare these phenomena between students with high perceptions with low self-efficacy.

\section{Participants}

The participants were students of the guidance and counseling study program of STKIP Sekolah Tinggi Keguruan dan Ilmu Pendidikan PGRI Sumatera Barat, Indonesia which consisted of 100 students of all classes in 2014 academic year. They were final-year students, which already had experience and knowledge about their career direction in the future.

\section{Instruments}

An instrument that has been developed by authors based on social cognitive theory that is based on the rating scale of Bandura (Bandura, 1986). Rating scale develop by Bandura as an efficacy scale in learning academic, and with this scale researcher implemented this rating scale to a new instrument that develop with elaboration of efficacy aspect in career readiness. This self-efficacy instrument is used to uncover the condition of students' self-efficacy perceptions in the awareness of their career readiness, the Self Efficacy Scale in Career Readiness (SESCR). Using a rating scale from a score of 1-10, in each item that indicates Not Capable, Able and Very Capable in the career they will prepare. SESCR has fulfill prerequisite of internal consistency of reliability from cronbach alpha such 0,875 with level of significant 0,05. To confirm the findings of this SESCR such perception of student's selfefficacy in career readiness, the researchers also conducted field assessments through interviews and observations of respondents' self-efficacy behavior in preparing themselves for their next careers.

\section{Data Analysis}

Data analysis of this research was carried out through descriptive statistics through percentage techniques in each aspect of the self-efficacy perception variable regarding awareness of their career readiness. As well as the quantitative description results were confirmed with qualitative data through the analysis of narrative descriptions of interviews and observations about the behavior of the perception of their self-efficacy. As well as a comparison between high and low respondents with a perception of their self-efficacy through phenomenological narrative analysis in the field, and regression technique has implemented to predict a contribution of self-efficacy to students' awareness in career readiness.

\section{RESULTS AND DISCUSSION}

\section{Results}

The data collected through the SESCR instrument that has been responded by 100 students, it was obtained a description of the data in general that the majority of the students who have a high perception of self-efficacy seen from the total acquisition of the SESCR rating scale, and the descriptive analysis also reflects that their perception of self-efficacy about awareness of their readiness careers are also in the high category. To see in detail and specific conditions the source of perception of self-efficacy in students' career readiness awareness from the aspects of mastery experience, vicarious experience, social persuasion and emotional state, can be seen in the following section.

\section{Condition of Students Perception Self-Efficacy in Career Readiness Awareness}

Table 1 showed that there are 8 statements about mastery experience which related to the students' career readiness knowledge that forms their self-efficacy perceptions. From 100 respondents who gave answers to the SESCR, 66 respondents (66\%) were in the high classification of aspects of their mastery experience in their career readiness in the 80-40 
Table 1. Description of Student's Self-Efficacy in Career Awareness

\begin{tabular}{lcccc}
\hline \multirow{2}{*}{ Self-Efficacy Dimensions } & \multicolumn{2}{c}{ High $(80-40)$} & \multicolumn{2}{c}{ Low (39-0) } \\
\cline { 2 - 5 } & F & $\%$ & F & $\%$ \\
\hline Mastery Experience & 66 & 66 & 34 & 34 \\
Vicarious Experience & 69 & 69 & 31 & 31 \\
Social Persuasion & 76 & 76 & 24 & 24 \\
Emotional Condition & 70 & 70 & 30 & 30 \\
\hline
\end{tabular}

score range. While there are 34 respondents (34\%) who are classified as low in their mastery experience in their career readiness.

For the vicarious experience, there are 7 statements about the experience of observing models related to students' career readiness knowledge that shapes their perceptions of selfefficacy. From100 respondents who gave answers to SESCR, 69 respondents (69\%) were in the high classification of aspects of their vicarious experience which had an effect on their career readiness in the 70-35 score range. While there are 31 respondents (31\%) classified as low in their vicarious experience of their career readiness.

For the dimension of social persuasion, there are 7 statements about social persuasion that affect the perception of self-efficacy of the career readiness of students who shape their self-efficacy perceptions. Of the 100 respondents who gave answers to the SESCR, 76 respondents $(76 \%)$ found that they were in the high classification of aspects of social persuasion in their career readiness in the 70-35 score range. While there are 24 respondents $(24 \%)$ classified as low in social persuasion of their career readiness.

Dimension of Emotional Conditions states there are 8 items of statements regarding the emotional state related to emotional mastery of the career readiness of students that shape their perceptions of self-efficacy. From 100 respondents who gave answers to SESCR, 70 respondents $(70 \%)$ were in the high classification of emotional aspects in their career readiness in the 80-40 score range. While there are 30 respondents $(30 \%)$ classified as low in emotional states for mastering emotions about their career readiness.

\section{Analysis of the Phenomenon of Perception and Behavior of Student Self-Efficacy in Career Readiness}

Based on the findings from the previous SESCR data, it can be seen that the majority of students who have low self-efficacy perceptions of their career readiness viewed from the source of self-efficacy, it is found that they are at a 4-6 confidence rating level, ie they feel that they are sufficiently capable and able based on their perception of their career readiness in this matter as prospective counselors. To clarify the data from this SESCR, it is necessary to confirm the data again through surveys of the phenomenon of perception and real behavior of respondents taken randomly between respondents who have self-efficacy perceptions whose confidence rating is above 6 with respondents whose confidence rating is below 5 .

The phenomenon of respondents' self-efficacy perceptions of aspects of performance experience for career readiness is done through interviews and observations of learning behaviors and practices regarding respondent's knowledge. Respondent A is a BK student whose SESCR score found that the average confidence rating is 5-9, he explained that:

"I am a guidance and counseling student that I have to understand and practice my science in real life. Plus I also have experience as a speaker in student activities to motivate and train".

As for the behavioral phenomenon, through observation it was found that, A is always active in the lecture process, his attitude and communication apply the principle as a counselor, as well as the acquisition of values both theory and practice he has a satisfying value. In contrast to Respondent F, where the majority of his self-confidence ratings are in 3-5 
of his daily behavioral phenomena he has less interest in the knowledge and skills he is learning in college, plus his statement:

"Indeed, I studied BK but I feel that I am not ready as a counselor, maybe later I will work in another field as long as I am in the education family."

Likewise with the phenomenon of respondents' self-efficacy perceptions in the aspects of social persuasion, vicarious experiences and emotional states that have a real influence on the behavior and perceptions of their self-confidence in career readiness. As for $\mathrm{H}$ respondents who have achieved the total rating score of SESCR that:

"I try to learn every behavior, experience and what kind of person does an activity and I think if after finishing this lecture, how can I be prepared with my career as an undergraduate education in this counseling field. Because I have chosen this, my family is supportive so I will try to take lessons from the experiences of others and my own experience, even though I have experienced some difficulties".

In this case, respondent $\mathrm{H}$ gained self-readiness for his career through vicarious processes, mature social and emotional persuasion obtained so that his efficacy increased and his career readiness increased.

\section{Analysis Regression of Self Efficacy to Students' Awareness in Career Readiness}

Based on the findings from the previous SESCR data, and regression analysis used in this research tested to a 100 participatns with different gender of students such 50 male and 50 female in same grade. The detail of regression analysis in this research can be seen in the Table 2.

According to Table 2, self-efficacy has a significant prediction to a students' awareness in career readiness in male $(\beta=.827 ; p=<.05)$ and female $(\beta=.258 ; p=<.05)$. This findings are strengthening of Bandura (1999) that self-efficacy as a good prediction for an capability and self-behavior in activity not just a perception, also Zimmerman \& Schunk (2001) said that self-efficacy has a strong effect for self-regulated learning in capability to do something or tasks.

\section{Discussion}

This phenomenon of perception and behavior is evident, in the lessons of individuals who have high readiness in careers have a subject interest (interest in a material) related to their expertise later, so that the individual's involvement in lectures to practice (Reeve \& Tseng, 2011). This can also be seen through the observation that students who have good selfefficacy about their career capabilities will be better equipped to explore their expertise from theory to practice than students who do not yet have a good perception of self-efficacy of their career readiness.

Based on the collection of field data obtained through SESCR, it is explained that from 100 respondents of 2014 class year students who are final year students have the perception of self-efficacy of their career readiness as prospective counselors, it can be seen that in every aspect of self-efficacy sources 66 are for the high-performance experience categories, and 69 vicarius high categories experience and social persuasion with emotional states 76 and 70 . This explains that in general the majority of the students already have an understanding of

Table 2. Regression Analysis of Self Efficacy to Students' Awareness in Career Readiness

\begin{tabular}{lccc}
\hline Gender & $\beta$ & $\mathrm{t}$ & $\mathrm{p}$ \\
\hline Male & .827 & 19.349 & $<.05$ \\
Female & .258 & 4.247 & $<.05$ \\
\hline
\end{tabular}


their careers. But, the reality of the field after collecting data through SESCR and observing the phenomenon of perception and behavior in the field, it was found that from a total of 100 respondents, only $60-70 \%$ of respondents had good self-efficacy perceptions so that their career readiness was good too. The rest becomes things that need to be followed up on. These findings are in line with research findings relating to the contribution of self-efficacy as a fundamental point in human social learning activities, that self-efficacy has a significant influence on the cognitive behavior of individuals in social systems (Alfaiz et al., 2015). As well as being an aspect that predicts the readiness of students in academic activities of their college assignments (Alfaiz et al., 2017a, 2017b).

Basically, the perception of self-efficacy is an individual's cognitive drive to make each learning experience a psychological force for adapting and directed behavioral actions in accordance with the learning process (Bandura, 1986; Pajares \& Usher, 2008; Pajares, 2006). It is shows the power of self-motivation, self-regulation, raises cognitive considerations, (Hergenhahn \& Olson, 2008) as well as choosing a form of choice that suits the individual's self potential (Pajares \& Usher, 2008; Bandura, 1986, 1999). In other words, individuals are capable of reconstructing and modifying every experience and knowledge they get, both direct experience and experience through observation processes, all of which they analyze in selecting, determining, and deciding and bringing up new behaviors that they are experts in (Pajares \& Miller, 1994; Pajares, 2002; Alfaiz et al., 2019a).

The process is a triadic reciprocal process in the social system in this case is in the realm of education in tertiary institutions, where students should be able to modify and reconstruct their experiences gained through direct experience, vicarious experience, social persuasion to emotional states so as to emerge skills and their career readiness Based on the findings above, it appears that students who are high in the aspect of the source of selfefficacy, they have consideration, motivation and make their choices with the career they want, in contrast to students who have not maximized their cognitive potential and behavior in modifying any knowledge they have acquired for their self-maturity . The perception of self-efficacy can also shape the personality of students in their capabilities and characteristics of skills in learning and career (Ahmadi, 2009; Alfaiz et al., 2017b).

Behavior that is seen from the findings of the field phenomenon that students who have a good perception of self-efficacy in their career readiness, they are actively involved, proactive and have motivation in academic activities and practice in their expertise. This is described from the results of research that the involvement of individuals in the learning process and practice is due to the self-efficacy drive that makes individuals as agents or actors of their own behavior (Reeve \& Tseng, 2011). Likewise in classroom learning activities that collaboration between individuals in the learning process raises a good social system climate because they have the same perception of self-efficacy making them actors of cognitive behavior (Montenegro, 2019; Alfaiz et al., 2019b, 2020).

If the perception of self-efficacy has an influence and increases awareness of students' career readiness based on survey results using SESCR and analysis of student behavior phenomena. So this can be a special concern in higher education and especially for educational counseling to prepare students ready for their careers. Individuals become actors for their behavior in the social environment in this case is their educational environment due to the existence of self-efficacy mechanisms for their own capabilities (Bandura, 1986, 2000), even the perception of self-efficacy is also very much needed to improve the ability of adaptation and motivation in social systems which are dynamic systems (Bandura, 2008). In other words, the findings through the SESCR survey and observation of student behavior phenomena explain that the perception of self-efficacy has a good contribution in raising awareness of student career readiness. 


\section{Limitations and Sugestions}

According the findings above, this research was limited in how the perception of self efficacy has a contribution to awareness of career readiness with data were collected through quantitative and qualitative method also a comparison and spesification within a number of survey between high level sample and low level sample. But in the future research this found will be more prospective in developing such a counseling approach to activating and increasing a student's awareness in their self efficacy.

\section{Implications}

Curret study showed that the perception of self-efficacy has a good contribution in raising awareness of student career readiness. This finding would has implication in the practice of guidance and counseling that educators or college counselors who must help and find ways and approaches to improve students' self-readiness for their careers and consider to improve their self-efficacy first.

\section{CONCLUSIONS}

The condition of students' self-efficacy perceptions related to the awareness of their career readiness makes students have a good awareness to be involved and active to improve their ability to have their career readiness after completing their studies. It was found that respondents who have the potential to modify performance experience which is one aspect of the source of self-efficacy make their behavior and ability to be actively involved and have confidence in conducting work practices as prospective counselors. Likewise, individuals who have good aspects of vicarious experience consider and decide to follow the learning process like the model they are observing so that direct experience with indirect experience becomes a source of self-efficacy that is mutually confirmed and construction with each other. It is different from individuals who are low on aspects of the source of self-efficacy, the impact on the perception of self-efficacy in their career readiness. They lack motivation, awareness of their goals and how to prepare themselves for their careers. Also from regression analysis found that self-efficacy has a good prediction for students' awareness in their career readiness with significant.

\section{ACKNOWLEDGMENTS}

We are grateful to all parties who have involved and contributed to this study and process in writing this manuscript. The authors have no funding to report.

\section{AUTHOR CONTRIBUTIONS STATEMENT}

All authors in this research team contributed according to their respective expertise with the maximum process. Such arrangement an instrumentation, distribution instrument to respondents, writing a research report, analyze the data collection and writing a blue print manuscript also completion the article.

\section{REFERENCES}

Ahmadi, A. (2009). Psikologi Sosial Cetakan ke 3 Edisi Revisi. Jakarta: PT Rineka Cipta. Google Scholar

Alfaiz, A., \& Yandri, H. (2015). Self concept and self efficacy as a ground points in a social activities (an analysis of psychology perspective: a social cognitive theory). Jurnal Pelangi, 7(2). https://doi.org/10.22202/jp.2015.v7i2.203

Alfaiz, A., Zulfikar, Z., \& Yulia, D. (2017a). Efikasi Diri sebagai Faktor Prediksi Kesiapan Mahasiswa dalam Mengerjakan Tugas Kuliah. Ilmu Pendidikan: Jurnal Kajian Teori 
dan Praktik Kependidikan, 2(2),

119-124.

http://dx.doi.org/10.17977/um027v2i22017p119

Alfaiz, A., Rafiola, R. H., Hariko, R., \& Zulfikar, Z. (2017b). Condition and Shaping of Student Personality in Educational Process Through Transpersonal Psychology Perspective. In 3rd International Conference on Education and Training (ICET 2017) (pp. 1-4). Atlantis Press. https://dx.doi.org/10.2991/icet-17.2017.1

Alfaiz, A., Hidayah, N., Hambali, I. M., \& Radjah, C. (2019a). Human Agency as a SelfCognition of Human Autonomous Learning: A Synthesized Practical of Agentic Approach. Journal of Social Studies Education Research, 10(4), 370-391. Google Scholar

Alfaiz, A., Yandri, H., Yuzarion, Y., Lestari, L. P. S., \& Heriyani, E. (2019b). Persepsi agentik individu untuk mencapai prestasi pribadi dalam aktivitas karir: riset pendahuluan. Psychocentrum Review, 1(2), 85-95. https://doi.org/10.26539/pcr.1276

Alfaiz, R. H. R., Triyono, M. D., \& Septya Suarja, N. (2020). Student Personal Agency Weakness in Autonomous Learning: Preliminary Research. International Journal of Innovation, Creativity and Chang, 13(7). 973-989. Google Scholar

Allred, S. L., Harrison, L. D., \& O'connell, D. J. (2013). Self-efficacy: An important aspect of prison-based learning. The Prison Journal, 93(2), 211-233. http://doi.org/10.1177/0032885512472964

Bandura, A. (1978). The self system in reciprocal determinism. American psychologist, 33(4), 344. http://doi.org/10.1037/0003-066x.33.4.344

Bandura, A., \& McClelland, D. C. (1977). Social learning theory (Vol. 1). Prentice Hall: Englewood cliffs. Google Scholar

Bandura, A. (1999). Social cognitive theory: An agentic perspective. Asian journal of social psychology, 2(1), 21-41. https://doi.org/10.1111/1467-839X.00024

Bandura, A. (2001). Social cognitive theory: An agentic perspective. Annual review of psychology, 52(1), 1-26. https://doi.org/10.1146/annurev.psych.52.1.1

Bandura, A. (2008). Toward an agentic theory of the self. Advances in self research, 3, 15-49. Google Scholar

Bandura, A. (2006). Toward a psychology of human agency. Perspectives on psychological science, 1(2), 164-180. http://doi.org/10.1177/1745691617699280

Bandura, A. (2000). Exercise of human agency through collective efficacy. Current directions in psychological science, 9(3), 75-78. https://doi.org/10.1111\%2F1467-8721.00064

Bandura, A. (1995). Self-efficacy in changing societies. Cambridge university press. Google Scholar

Bandura, A. (1986). Social foundations of thought and action. Englewood Cliffs, NJ, 1986(2328). Google Scholar

Boeree, G. (2004). Personality Theories, terj. Inyiak Ridwan Muzir. Yogya: Primasophie. Google Scholar

Cauce, A. M., \& Gordon, E. W. (2012). Toward the measurement of human agency and the disposition to express it. Gordon commission on the future of educational assessment,

Princeton, Educational Testing Service. Google Scholar

Chongvilaivan, A. (2016). Does Outsourcing Enhance Skill Premiums in ASEAN?. In ASEAN Economic Community (pp. 217-229). Palgrave Macmillan, New York. http://doi.org/10.1057/9781137535085_11

Gao, Z., Lochbaum, M., \& Podlog, L. (2011). Self-efficacy as a mediator of children's achievement motivation and in-class physical activity. Perceptual and Motor Skills, 113(3), 969-981. http://doi.org/10.2466/06.11.25.PMS.113.6.969-981

Hergenhahn, B. R., \& Olson, M. H. (2008). Theories of Learning (teori belajar). Tri Wibowo BS (Alih bahasa). Jakarta: Kencana Prenada Media Group. Google Scholar 
Cramer, S. H., Herr, E. L., \& Niles, S. G. (2004). Career guidance and counseling through the lifespan. Boston, MA: Pearson Education Inc. Google Scholar

Kemendikbud, T. P. (2014). Konsep Dan Pedoman Penguatan Pendidikan Karakter Tingkat Sekolah Dasar Dan Menengah Pertama. Jakarta: Kementerian Pendidikan Dan Kebudayaan Republik Indonesia. Google Scholar

Krumboltz, J. D., Mitchell, A. M., \& Gelatt, H. B. (2011). Krumboltz's learning theory of career counseling (LTCC) \& happenstance. Google Scholar

Montenegro, A. (2019). Why are students' self-initiated contributions important (?) A study on agentic engagement. International Journal of Sociology of Education, 8(3), 291-315. http://dx.doi.org/10.17583/rise.2019.4540

Pajares, F. (2002). Self-efficacy beliefs in academic contexts: An outline. Google Scholar

Pajares, F. (2006). Self-efficacy during childhood and adolescence. Self-efficacy beliefs of adolescents, 5, 339-367. Google Scholar

Pajares, F., \& Miller, M. D. (1994). Role of self-efficacy and self-concept beliefs in mathematical problem solving: A path analysis. Journal of educational psychology, 86(2), 193. https://psycnet.apa.org/doi/10.1037/0022-0663.86.2.193

Pajares, F., \& Usher, E. L. (2008). Self-efficacy, motivation, and achievement in school from the perspective of reciprocal determinism. Advances in motivation and achievement, 15, 391-423. Google Scholar

Reeve, J., \& Tseng, C. M. (2011). Agency as a fourth aspect of students' engagement during learning activities. Contemporary Educational Psychology, 36(4), 257-267. http://doi.org/10.1016/j.cedpsych.2011.05.002

Umar, H. (2008). Metode Penelitian untuk skripsi dan tesis Bisnis edisi Kedua. Jakarta: PT RajaGrafindo Persada. Google Scholar

Wicaksono, A. (2007). Think ASEAN! Rethinking Marketing toward ASEAN Community 2015. ASEAN Economic Bulletin, 24(2), 278-80. http://doi.org/10.1355/ae24-2h

Zimmerman, B. J., \& Schunk, D. H. (Eds.). (2001). Self-regulated learning and academic achievement: Theoretical perspectives. Routledge. Google Scholar

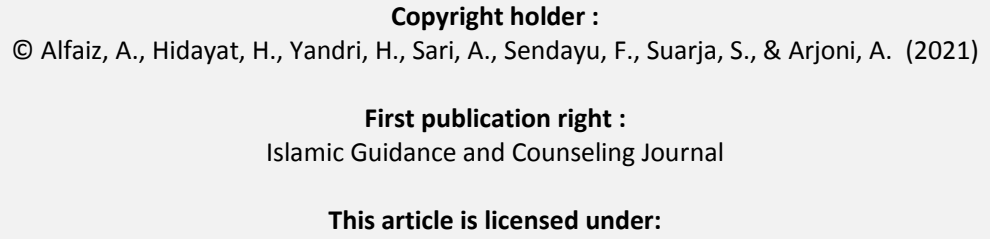

Copyright holder :

(c) Alfaiz, A., Hidayat, H., Yandri, H., Sari, A., Sendayu, F., Suarja, S., \& Arjoni, A. (2021)

First publication right :

Islamic Guidance and Counseling Journal

This article is licensed under: 